\title{
A TECHNIQUE FOR STUDYING THE ACTION OF ANTISEPTICS ON BACTERIA IN SUBCUTANEOUS TISSUES, WITH SPECIAL REFERENCE TO CHLORHEXIDINE
}

\author{
BY \\ A. R. MARTIN \\ From the Research Department, Imperial Chemical Industries Limited Pharmaceuticals Division, \\ Alderley Park, Macclesfield, Cheshire
}

(RECEIVED FOR PUBLICATION JULY 3, 1958)

Bacteria which gain access to a freshly inflicted wound are at first external to the tissues and do not immediately cause any reaction. During this stage, which is commonly said to last up to about six hours, the wound is described as contaminated, and the organisms in it may be susceptible to antiseptics. Later, when bacteria have invaded the tissues, the wound is described as infected, and locally applied antiseptics are at a great disadvantage. The great differences which exist (and the difficulties in defining them) between accidental wounds in man and animals in respect of the age and nutritional status of the subject on the one hand, and the nature, site, severity, and degree of contamination of the wound on the other, have made the task of carrying out adequately controlled clinical trials of the value of antiseptics extremely formidable. In fact, only two such trials have been carried out, one by Williams and Miles (1949) dealing with several antiseptics, and a co-operative one carried out by groups of American workers on the value of locally applied sulphonamides reported by Meleney (1945). A study on a smaller scale, but carried out in great bacteriological detail, was reported by Florey, Ross, and Turton (1947).

These difficulties have led to several attempts to establish experimental wounds in which the degree of trauma and of bacterial contamination and the manner of treatment were controlled. In some methods bacteria have been injected subcutaneously or rubbed into superficial cuts, treatment being given on one or several occasions by swabbing or irrigation or by subcutaneous injection into or around the contaminated site (Browning and Gulbransen, 1925, 1928 ; Collier and Bernhagen, 1928 ; Hata, 1932 ; Morgenroth and Abraham, 1920 ; Reinhardt, 1922 ; Schiemann, 1922). Gordon, McLeod, Meyr-Harting, Orr, and
Zinnemann (1947) removed an ellipse of skin, contaminated the raw area with streptococci, and treated it by dropping on antiseptic solutions. These methods have failed to control one or more of the following variables: (1) The number of organisms implanted in or on the tissues; (2) the amount of antiseptic in contact with the contaminated tissues; (3) the length of time for which the antiseptic acts. The third point is particularly difficult to meet, because any form of bandaging of small animals is almost impracticable. It is believed that the method described below, whilst not imitating the treatment of traumatic wounds, goes far towards controlling the above variables.

The present method is based upon two simple steps: (1) The subcutaneous injection of a small measured volume of a suspension of an organism capable of causing the death of the animal ; (2) the injection of a somewhat larger volume of antiseptic into the same site shortly afterwards.

Since the site of injection of the organisms is practically bloodless, a closer approach to the conditions in a traumatic wound may be made by suspending the bacteria and dissolving or suspending the antiseptic separately in sterile, defibrinated blood. The degree of success of any antiseptic treatment is assessed by comparing the number of survivors in the treated and control groups (since a test organism is used which causes the death of all untreated animals at the dose injected) and the mean survival times of those which die in the two groups.

The method seems to be applicable to any experimental animal, but it has in fact been applied only to mice. The experiments have been referred to as relating to the treatment of "wounds" (in inverted commas because the method involves so little trauma). 


\section{Materials}

Anaesthetic.-One part of a stock solution of tribromethanol in amylene hydrate containing $1 \mathrm{~g}$. in 1 ml. (" avertin," Bayer Products Ltd., Eden Street, Kingston-on-Thames) was diluted in 39 parts of $10 \%$ ethyl alcohol. The dilute $(2.5 \%)$ solution was made freshly for each experiment. This anaesthetic was found far superior to pentobarbitone for this purpose, because deaths from the anaesthetic did not occur.

Bacterial Suspension.-A stock culture of Streptococcus pyogenes, Kruger strain, in cooked-meat broth was kept in the refrigerator. For use, $0.5 \mathrm{ml}$. of the supernatant of this broth was added to $3 \mathrm{ml}$. of Wright's broth containing $5 \%$ of horse blood. This was incubated overnight at $37^{\circ} \mathrm{C}$. and one part was diluted in 1,000 parts of plain broth or of $90 \%$ horse blood, according to need.

Antiseptics.-These were used as solutions or suspensions in water or in $90 \%$ horse blood (prepared by adding 1 volume of strong antiseptic to 9 volumes of blood). Where necessary, a non-toxic, non-ionic dispersing agent was used. The strength of the antiseptic solutions was limited to that shown in preliminary experiments to cause no obvious distress to the animals when $0.2 \mathrm{ml}$. was injected subcutaneously.

\section{Methods}

Basic Method.-Ten mice (18-22 g.) were anaesthetized by the intraperitoneal injection of $0.2 \mathrm{ml}$. of $2.5 \%$ tribromethanol (i.e., a dose of $5 \mathrm{mg} . / 20$ g.). Six minutes later all the mice were usually " sleeping" quietly. A No. 1 hypodermic needle was then inserted subcutaneously along the back for a distance of about 1 in. and $0.05 \mathrm{ml}$. of bacterial suspension was injected from a tuberculin syringe. The syringe was detached, leaving the needle in sifu, and the mouse placed carefully on its side. A fresh needle was attached to the syringe, the plunger adjusted to the next mark and $0.05 \mathrm{ml}$. injected into the second mouse as before. The remaining mice were treated in the same way.

Twenty minutes after the first mouse had been infected it was treated with $0.2 \mathrm{ml}$. of antiseptic injected through the indwelling needle, taking care to alter its position as little as possible. All the mice were treated similarly in turn. After each mouse was treated, the needle was removed and the mouse returned to its cage. A group of control mice was injected with the bacterial suspension followed by saline.

Mice usually began to recover from the anaesthetic after about $\mathbf{3 0}$ minutes, and in two or three hours they were usually quite active. It was occasionally found that a mouse was not sufficiently under the influence of the anaesthetic at some stage. If so, the intraperitoneal injection of about $0.05 \mathrm{ml}$. of the anaesthetic solution almost always produced satisfactory relaxation in a minute or two.

Modifications of the Basic Method.-Three modifications for different effects were employed.
Addition of Blood.-To make the conditions a more severe test of the effectiveness of any treatment, both the infecting organism and the antiseptic treatment were prepared and injected in horse blood. This was done by preparing both the culture and antiseptic at 10 times the required strength and then adding 1 volume of each (separately) to 9 volumes of sterile horse blood. The other manipulations proceeded as described above. Control experiments showed that mice died at the same rate when the organisms were suspended in blood as when they were suspended in broth. The two types of experiment are distinguished in tables of results by showing the "vehicle" as "water" or " blood."

Comparison of Local with Systemic Action.-It was necessary in certain instances to decide whether the action of any particular antiseptic was exerted directly upon the organisms at the site of their injection, or was the secondary result of its absorption and systemic distribution. This was done by comparing two groups of animals, one treated as already described and the other "treated" locally with saline injected down the original needle, and at some remote site with the same dose of the same preparation as was used to treat the first group.

Delay in Treatment.-To demonstrate the effect of a delay in treating the subcutaneously deposited organisms, several groups of mice were anaesthetized and the organisms injected in the usual way. Successive groups were treated with antiseptic after the desired intervals, anaesthesia being maintained by occasional injections of small doses of tribromethanol, as required. Mice have been maintained under continuous anaesthesia in this way for six hours.

\section{Results}

An example of the results to be expected from the application of the technique described above is given in Table I, which shows the effects of

TABLE I

TREATMENT OF STREPTOCOCCAL “WOUNDS" WITH THERAPEUTIC AGENTS APPLIED LOCALLY AND SYSTEMICALLY

\begin{tabular}{|c|c|c|c|}
\hline Treatment & $\begin{array}{c}\text { Site of } \\
\text { Treatment }\end{array}$ & $\begin{array}{c}\text { Total } \\
\text { Deaths }\end{array}$ & $\begin{array}{c}\text { Mean } \\
\text { Survival } \\
\text { Time of } \\
\text { Mice } \\
\text { Dying } \\
\text { (Days) }\end{array}$ \\
\hline $\begin{array}{l}\begin{array}{l}\text { Penicillin G }(0.07 \% \text {, i.e., } \\
\text { units } / \text { ml.) }\end{array} \\
\begin{array}{l}\text { Streptomycin }(0.5 \% \text {, i.e., } \\
\text { units ml.) } \\
\text { Chlortetracycline }(0.025 \%)\end{array} \\
\begin{array}{l}\text { Sulphadimidine }(3 \%) \\
\text { Chlorhexidine diacetate }(0.1 \%)\end{array} \\
\begin{array}{llr}\text { Saline (controls) } & \ldots & \ldots\end{array}\end{array}$ & $\begin{array}{l}\text { Local } \\
\text { Remote } \\
\text { Local } \\
\text { Remote } \\
\text { Local } \\
\text { Remote } \\
\text { Local } \\
\text { Remote } \\
\text { Local } \\
\text { Remote } \\
\text { Local } \\
\text { Remote }\end{array}$ & $\begin{array}{r}9 \\
10 \\
2 \\
8 \\
7 \\
8 \\
7 \\
8 \\
1 \\
10 \\
10 \\
10\end{array}$ & $\begin{array}{l}3 \cdot 1 \\
2 \cdot 8 \\
3 \cdot 0 \\
3 \cdot 5 \\
3 \cdot 4 \\
2 \cdot 8 \\
3 \cdot 1 \\
4 \cdot 6 \\
3 \cdot 0 \\
2 \cdot 3 \\
2 \cdot 3 \\
2 \cdot 3\end{array}$ \\
\hline
\end{tabular}

All treatments given 20 minutes after infection to groups of 10 mice. 
some antibiotics and a sulphonamide under the conditions described above.

It will be seen that the results with penicillin, chlortetracycline, and sulphadimidine were very similar whether these drugs were given locally or at a remote site. With streptomycin, local treatment was considerably more effective. This is in accordance with Garrod's (1948) demonstration that streptomycin is much more rapidly bactericidal than penicillin. The ineffectiveness of the single application of penicillin may be noted: Williams and Miles (1949) observed that a single application of penicillin to accidental wounds did not reduce the sepsis rate. Remote treatment with chlorhexidine diacetate was quite ineffective, as would be expected from its known lack of systemic activity (Davies, Francis, Martin, Rose, and Swain, 1954), but when applied locally it was highly effective.

The technique described above was devised during laboratory studies on chlorhexidine, many of which were carried out in order to compare the new antiseptic with older ones. Various salts of chlorhexidine have been examined over a range of concentrations on 28 occasions. These salts have included the relatively soluble $(1.9 \%)$ diacetate, the less soluble hydrochloride $(0.2 \%)$, and the very sparingly soluble $(0.01 \%)$ carbonate, silicate, and metaphosphate. In direct comparison with one another all appeared to be equally effective. The results obtained are summarized in Table II, in which no distinction has been made

\section{TABLE II}

RESULTS OF TREATING STREPTOCOCCAL “ WOUNDS" WITH CHLORHEXIDINE SALTS

\begin{tabular}{c|c|c|c}
\hline $\begin{array}{c}\text { Strength of } \\
\text { Chlorhexidine } \\
\text { Salt Used }\end{array}$ & $\begin{array}{c}\text { No. of } \\
\text { Mice } \\
\text { Treated }\end{array}$ & $\begin{array}{c}\text { No. of } \\
\text { Mice } \\
\text { Dead }\end{array}$ & $\begin{array}{c}\text { Percentage } \\
\text { Survivors }\end{array}$ \\
\hline 0 (controls) & 280 & 280 & 0 \\
$0.1 \%$ & 190 & 32 & 83 \\
$0.05 \%$ & 50 & 9 & 82 \\
$0.02 \%$ & 30 & 12 & 60 \\
$0.01 \%$ & 10 & 1 & 90 \\
\hline
\end{tabular}

between the various salts. It is clear that a highly significant effect was produced by the treatments.

The effect of increasing the interval between the deposition of organisms subcutaneously and the application of the antiseptic was studied. Seven groups of mice were anaesthetized and given the usual subcutaneous injection of diluted streptococcal culture. At intervals of 20 minutes, one hour, two, four, and six hours thereafter, groups were treated with chlorhexidine diacetate solution $(0.1 \%)$ in the usual way, the original needle being left in situ and the mice maintained in a state of anaesthesia by occasional further intraperitoneal injections of tribromethanol. In this experiment, $90 \%$ horse blood was used as the vehicle for both the infecting organisms and the antiseptic (see below). Two control groups were included, one treated with saline in $90 \%$ blood after 20 minutes and one after six hours. The results are shown in Table III.

TABLE III

EFFECT OF DELAY IN TREATMENT OF STREPTOCOCCAL "WOUNDS"

\begin{tabular}{c|c|c}
\hline $\begin{array}{c}\text { Interval between } \\
\text { Injection of Organisms } \\
\text { and Treatment }\end{array}$ & $\begin{array}{c}\text { Total } \\
\text { No. of } \\
\text { Deaths }\end{array}$ & $\begin{array}{c}\text { Mean Survival Time } \\
\text { of Mice Dying } \\
\text { (Days) }\end{array}$ \\
\hline 20 minutes & 3 & $4 \cdot 3$ \\
1 hour & 1 & 3.0 \\
4 hours & 1 & $2 \cdot 0$ \\
6 ", & 4 & 3.6 \\
Controls: & 6 & 2.6 \\
20 minutes & 10 & $3 \cdot 0$ \\
6 hours & 10 & $2 \cdot 4$ \\
\hline
\end{tabular}

All "wounds" treated with chlorhexidine diacetate, $0 \cdot 1 \%$, in $90 \%$ horse blood. Controls treated with saline in $90 \%$ horse blood. Groups of 10 mice.

The mean survival time of the mice which died was approximately the same in all groups, although more mice died in the groups treated after a long interval than in those treated promptly. This could have been due to gradual displacement of the indwelling needle. However, some mice were saved by the delayed treatments, indicating that organisms still accessible to the antiseptic were controlled by it.

The antiseptic powers of chlorhexidine under these experimental conditions have been compared with those of proflavine hemisulphate and $m$-chloroxylenol (Table IV), and also with those of various quaternary ammonium compounds (Table V). The experiment summarized in Table IV was carried out in two parts, in one of which

TABLE IV

TREATMENT OF STREPTOCOCCAL “WOUNDS" WITH CHLORHEXIDINE, PROFLAVINE HEMISULPHATE, AND $m$-CHLOROXYLENOL

\begin{tabular}{l|c|c|c}
\hline \multicolumn{1}{c|}{ Treatment } & Vehicle & $\begin{array}{c}\text { Total } \\
\text { Deaths }\end{array}$ & $\begin{array}{c}\text { Mean } \\
\text { Survival } \\
\text { Time of } \\
\text { Mice } \\
\text { Dying } \\
\text { (Days) }\end{array}$ \\
\hline Chlorhexidine diacetate, 0.05\% & Saline & 5 & 3.0 \\
Proflavine hemisulphate, 0.1\% & Blood & 3 & 2.8 \\
m-Chloroxylenol solution, 5\%* & Saline & 6 & 2.7 \\
None (controls) & Saline & 14 & 3.0 \\
& Blood & 20 & 2.5 \\
& & 20 & 1.7 \\
\hline
\end{tabular}

Each group comprised 20 mice.

* Commercial solution containing $4.8 \%$ of $m$-chloroxylenol, i.e. treatment given contained $0 \cdot 24 \%$ of antiseptic, the manufacturer's recommended concentration. 
TABLE V

TREATMENT OF STREPTOCOCCAL “WOUNDS" WITH CHLORHEXIDINE AND QUATERNARY AMMONIUM COMPOUNDS

\begin{tabular}{|c|c|c|}
\hline Treatment & $\begin{array}{c}\text { Total } \\
\text { Deaths }\end{array}$ & $\begin{array}{l}\text { Mean Survival } \\
\text { Time of Mice } \\
\text { Dying (Days) }\end{array}$ \\
\hline 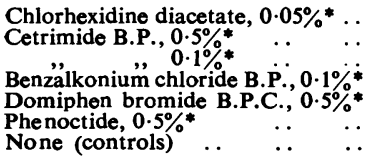 & $\begin{array}{r}0 \\
8 \\
10 \\
10 \\
9 \\
10 \\
10\end{array}$ & $\begin{array}{l}-3 \cdot 0 \\
2 \cdot 4 \\
2 \cdot 6 \\
2 \cdot 7 \\
1 \cdot 6 \\
2 \cdot 1\end{array}$ \\
\hline
\end{tabular}

Organisms and drugs were administered in $90 \%$ blood. Each group comprised 10 mice.

* Concentration recommended by the manufacturer for the treatment of wounds.

the vehicle for streptococci and antiseptics was saline and in the other was $90 \%$ horse blood.

From the results summarized in Tables IV and $\mathrm{V}$ it is clear that the marked effect of chlorhexidine under these conditions is unaffected by the presence of blood. There was a significant reduction of the action of proflavine when blood was present. The effects produced by the other antiseptics were very slight.

Experiments in which iodine, as a $0.5 \%$ solution in potassium iodide, the strongest which could be used, was the antiseptic, were carried out on six occasions in the presence and the absence of added blood. The results, which were very variable, are summarized in Table VI. There is no doubt that

TABLE VI

TREATMENT OF STREPTOCOCCAL "WOUNDS" WITH IODINE IN PRESENCE AND ABSENCE OF BLOOD

\begin{tabular}{|c|c|c|c|}
\hline Treatment & & & No. of Mice Dead \\
\hline $\begin{array}{l}0.5 \% \text { iodine in water } \\
\text { None (controls) } \ldots 0 \% \text { blood } \\
\ldots\end{array}$ & $\begin{array}{l}\cdots \\
\ldots \\
\ldots\end{array}$ & $\begin{array}{l}\cdots \\
\cdots \\
\cdots\end{array}$ & $\begin{array}{l}30 \text { out of } 60 \\
37,, \quad, \quad 39 \\
60,, \quad, \quad 60\end{array}$ \\
\hline
\end{tabular}

iodine is an efficient antiseptic for the destruction of organisms on the surface of the skin (Gardner, 1948), but its value as a disinfectant of wounds is unproved, as with all other disinfectants. The present tests showed a very marked reduction of activity in the presence of blood.

A number of substances which have been used as antiseptics for many years have been examined on various occasions. Without giving the results in detail, it may be said that mercuric oxycyanide $(0.05 \%)$, mercuric biniodide $(0.1 \%), 2: 7$-dibromo4-hydroxymercurifluorescein $(0.1 \%)$, 8-hydroxyquinoline $(0.1 \%)$, potassium permanganate $(0.1-$ $1.0 \%)$, phenol $(0.25-1.0 \%)$, and iodoform $(1.0 \%)$ were without action, mercuric chloride $(0.01 \%)$, sodium ethylmercuri-thiosalicylate $(0.02-0.1 \%)$, and silver proteinate, Argyrol type (5\%), showed a doubtful effect, whilst crystal violet $(0.1 \%)$ and malachite green $(0.1 \%)$ were slightly active. Acriflavine as a $0.1 \%$ aqueous solution was clearly active, but acriflavine emulsion B.P.C. was much less effective. The use of 4-aminomethylbenzene sulphonamide ("marfanil") (3\%), used as a dusting powder for wounds by the German forces, was without effect.

\section{Summary and Conclusions}

The technique described has proved easy to carry out and has given reasonably reproducible results, although great precision cannot be claimed for it. The observations of Hewitt (1954) suggest that in the basic procedure described above the injected bacteria are surrounded by the subsequently injected antiseptic solution. It is difficult to imagine that a substance which is inactive under these rather favourable conditions could be very effective in clinical practice, but we cannot conclude that the converse is true. Results unduly favourable to any particular antiseptic used are not likely to be obtained, because the most probable error, accidental movement of the indwelling needle in the interval between infecting and treating the mice, would lead to misplacement of the antiseptic, with a consequent reduction of activity. This may, indeed, be the cause of the few early deaths often observed in groups treated with what appear to be, from the satisfactory condition of the bulk of mice in the group at the end of a week, effective treatments.

The technique appears capable of differentiating between compounds of marked inhibitory action in vitro, and also shows the marked reduction in activity in vivo which occurs with some substances when an excess of blood is introduced into the system. Chlorhexidine compares favourably with many other antiseptics under these experimental conditions.

\section{REFERENCES}

Browning, C. H., and Gulbransen, R. (1925). Brit. med. J., 1, 688. Col (1928). J. Pharmacol., 34, 187.

Collier, W. A., and Bernhagen, I. (1928). Z. Hyg. Infekt.-Kr., 109, 383.

Davies, G. E., Francis, J., Martin, A. R., Rose, F. L., and Swain, G. (1954). Brit. J. Pharmacol., 9, 192.

Florey, M. E., Ross, R. W. N. L., and Turton, E. C. (1947). Lancet, $1,855$.

Gardner, A. D. (1948). Ibid., 2, 760.

Garrod, L. P. (1948). Brit. med. J., 1, 382.

Gordon, J., McLeod, J. W., Mayr-Harting, A., Orr, J. W., and Zinnemann, K. (1947). J. Hyg. (Camb.), 45, 297.

Hata, S. (1932). Kitasato Arch. exp. Med., 9, 1.

Hewitt, H. B. (1954). Brit. J. exp. Path., 35, 35.

Meleney, F. L. (1945). Surg. Gynec. Obstet., 80, 263.

Morgenroth, J., and Abraham, L. (1920). Disch. med. Wschr., 46, 57.

Reinhardt, A. (1922). $\quad$ Z. Hyg. Infekt.-Kr., 95, 27.
Schiemann, O. (1922).

Williams, R. E. O., and Miles, A. A. (1949). Spec. Rep. Ser. med. Res. Coun. (Lond.), No. 266. 